\title{
Pemikiran Pendidikan Islam Syekh Muhammad Naquib Al-attas
}

\author{
Muslina ${ }^{1}$, Rini Rahman ${ }^{2}$ \\ ${ }^{12}$ Fakultas Ilmu Sosial, Universitas Negeri Padang, Indonesia \\ *Corresponding author, e-mail: linatinaya1999@gmail.com
}

\begin{abstract}
This study aims to discuss and examine the thoughts of Sheikh Muhammad Naquib Al-Attas about Islamic education. The method used is a literature study, which uses library data as a source. The results of the study reveal that there are 5 (five) important points of Sheikh Muhammad Naquib Al-Attas' thoughts related to education, namely: First, the purpose of education, namely to instill goodness or justice in humans as human beings and personal self which focuses on the formation of individual personalities and expects the formation of an ideal society, Second, Educational Methods, The method he mostly uses is Tawhid, Metaphors and Stories, Third, Educational Curriculum, is divided into Fardhu 'ain and fardhu kifayah, Fourth Educators, according to Al-attas Educators must have personality and manners Fifth, students, according to Al-Attas, students are required to develop perfect etiquette in science
\end{abstract}

Keywords: Thought, Education, Shaykh Muhammad Naquib Al-attas

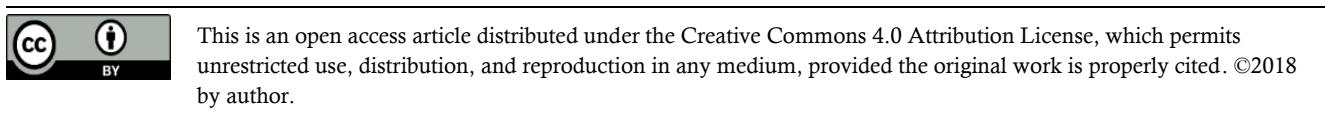

\section{Pendahuluan}

Barni (2008) mengatakan bahwa Pendidikan merupakan sebuah proses dan usaha yang di lakukan oleh orang dewasa secara sadar, terencana dan sistematis terhadap anak didik agar bisa hidup sesuai dengan tuntutan zaman yang selalu berubah dan berkembang. Muhaemin dan Bulu'k (2014) menegaskan bahwa pendidikan Islam merupakan suatu proses pembentukan individu berdasarkan ajaran Islam sesuai dengan tuntunan ajaran agama yakni Alquran dan Hadist yang tidak hanya dimaknai secara teoritis tetapi juga menuntut prakteknya dalam keseharian.

Pendidikan islam mengalami perubahan panjang yang tidak terlepas dari proses penyebaran islam dalam perkembangannya. Menurut Hafner (dalam Rengga Satria, 2019: 1-2) perkembangan pendidikan islam di Indonesia memiliki tiga poin penting. Pertama, Pengajian Alquran yaitu proses pendidikan untuk membaca dan menghafalkan Alquran, pengajian Alquran ditujukan untuk para pemula dalam mempelajari agama Islam. Kedua, Pondok Pesantren, yakni sistem pendidikan yang diterapkan melalui pengasramaan peserta didik di suatu tempat tertentu. Ketiga, Madrasah, yaitu lembaga yang didukung oleh pemerintah dalam mengajarkan pendidikan Islam salah satunya adalah pesantren yang merupakan lembaga pendidikan tertua di Indonesia.

Pendidikan Islam merupakan sistem pendidikan yang berupaya untuk melahirkan orangorang yang berilmu sesuai dengan cita-cita islam yang dapat merubah cara pandang individu menjadi lebih baik dari segala sisi, baik dari cara berfikir, tutur bahasa dan budi pekerti serta 
mampu menerapkan dan memperkenalkan nilai-nilai tersebut secara menyeluruh kedalam kehidupan bermasyarakat.

Pendidikan islam banyak mengalami pergeseran makna yang sesuai dengan perubahan sebuah konteks kemasyarakatan dan juga zaman, oleh karenanya para pemikir Pendidikan sesuai dengan latar belakang yang dimilikinya memiliki beragam pendapat mengenai Pendidikan Islam (Nanu, 2021). Lingkungan masyarakat, perkembangan zaman dan latar belakang mempengaruhi pola pikir seseorang.

Pendidikan Islam di Indonesia memerlukan rekonstruksi konsep dan sistemnya yang sesuai dengan moralitas dan nilai-nilai kemanusiaan, Pendidikan Islam di Indonesia masih jauh dari apa yang di harapkan (Hirnawan. 2020: 3). Keadaan yang menimpa dunia Pendidikan bersumber dari kekacauan intelektual dan hilangnya identitas kebudayaan yang disebabkan oleh pengaruh konsep, penafsiran dan makna ilmu itu sendiri. Disamping perencanaan yang buruk dan cara penanganan yang salah (Hirnawan. 2020: 4). Banyak hal yang harus diperhatikan ketika hendak memajukan Pendidikan Islam. Ketika Pendidikan maju maka peradaban pun akan maju. Karena, kemajuan Pendidikan akan menjadi faktor utama penyebab kemajuan peradaban Islam.

Menurut Ashraf (1989) kemunduran Pendidikan melambangkan adanya kelalaian yang terjadi dalam proses merumuskan dan mengembangkan rencana Pendidikan yang sistematis berdasarkan prinsip-prinsip Islam. Perlunya mengadakan penataan kembali dalam pendidikan Islam dari segi konseptual, sebenarnya telah lama disadari dan diupayakan oleh umat Islam. Kemunduran yang saat ini tengah melanda umat terutama dalam bidang pedidikan terjadi karena kelalaian kita daIam proses perencanaan pendidikan itu sendiri. Ketika hendak merencanakan pendidikan, maka langkah pertama adalah merumuskan tujuan yang hendak dicapai. Tujuan yang akan di rumuskan pada umumnya akan berkesesuain dengan pandangan hidup orang yang akan mendesain tersebut. Pikiran inilah yang menyebabkan ada beragam rumusan mengenai tujuan pendidikan.

Quraish Shihab misalnya, beliau merumuskan bahwa tujuan dari pendidikan Islam adalah untuk mencapai tujuan yang telah di isyaratkan dalam al-quran yaitu serangkain upaya yang dilakukan oleh seorang pendidik dalam rangka membantu peserta didik untuk dapat menjalankan fungsinya semaksimal mungkin, baik pembinaan dari aspek spiritual maupun material (Muhaemin \& Bulu'k, 2014).

Beberapa ahli pendidikan berpendapat bahwasannya tujuan dari pendidikan Islam adalah untuk membentuk kepribadian Muslim, diantaranya Ahmad D. Rimba, Arifin, dan Mahmud Sayyid Sulthan (Muhaemin \& Bulu'k, 2014). Mereka berpendapat bahwa tujuan utama dari pendidikan Islam yakni untuk membentuk pribadi muslim yang terdidik, beriman, bertaqwa yang mengacu pada tuntunan agama dan kebutuhan masyarakat.

Sejalan dengan itu Syafe'i (2015) juga merincikan secara spesifik bahwa tujuan pendidikan Islam adalah mengarahkan dan menyadarkan peserta didik agar menyadari tanggung jawabnya kepada Allah ta'ala sebagai ciptaannya dan juga sebagai makhluk sosial serta membimbing peserta didik agar menjadi pribadi yang lebih baik.

Ketika tujuan pendidikan sudah dirumuskan dengan sebaik mungkin diperlukan adanya metode guna memudahkan langkah agar tujuan tercapai. Asy'ari (2014) mendefenisikan metode sebagai seperangkat jalan, cara dan teknik yang dipakai dalam proses pembelajaran agar peserta didik dapat mencapai tujuan ataupun kompetensi tertentu yang telah di rumuskan dalam kurikulum, silabus dan mata pelajaran. Sementara itu Muhaemin \& Bulu'k (2014 : 75) 
menjelaskan bahwa metode adalah berbagai cara yang ditempuh oleh seorang pendidik yang ditempuh secara sistematis dalam proses pembelajaran yang telah diolah.

Begitu juga halnya dengan kurikulum pendidikan, kurikulum pendidikan ditentukan oleh tujuan pendidikan yang hendak dicapai, dan tujuan pendidikan yang akan dicapai ini ditetapkan berdasarkan keinginan dari yang membuat kurikulum. Menurut Nizar (dalam alhaddad, 2018) kurikulum merupakan arena bertanding, tempat peserta didik bertanding untuk menguasai berbagai pembelajaran agar bisa mencapai garis finish dalam bentuk ijazah dan yang sejenisnya. Alhaddad (2018) menjelaskan bahwa kurikulum merupakan program yang disediakan oleh sekolah dalam dunia pendidikan yang meliputi semua aspek yang dapat menjadi penunjang tumbuh kembang intelektual peserta didik sesuai tujuan pendidikan yang hendak dicapai dengan harapan mampu meningkatkan mutu kehidupannya menjadi lebih baik dari sebelumnya.

Setelah tujuan ditetapkan, metode di rancang, dan kurikulum juga telah ditentukan tentu harus ada pelaku yang menjalankannya yakni pendidik dan juga peserta didik. Ahmad Tafsir (dalam Saputra 2015) menyatakan bahwa pendidik adalah orang untuk mendidik. Secara spesifik pendidik dalam pendidikan Islam merupakan orang yang memiliki tanggung jawab terhadap tumbuh kembang peserta didik dengan segala upaya mengoptimalkan perkembangan semua aspek yang dimiliki peserta didik sesuai dengan kemampuan yang ia miliki mulai dari kognitif, afektif dan spiritual. Dikutip dari Abudin nata (dalam Saputra, 2015) pendidik adalah orang yang bertanggung jawab terhadap perkembangan seluruh potensi peserta didik, memberikan pengetahuan, mengajarkan keterampilan, memberikan pembelajaran emosial.

Sejalan dengan itu Saputra ( 2015) menegaskan bahwa pendidik bukan hanya orang yang bertugas di sekolah saja, tetapi juga semua orang yang mengambil peran dalam proses pendidikan anak sejak dini, mulai dari dalam kandungan hingga dewasa. Pendidik juga merupakan orang yang bertanggung jawab terhadap perkembangan jasmani dan rohani peserta didik sehingga ia mampu menjalankan fungsi dan perannya secara maksimal sesuai dengan nilai-nilai ajaran Islam. Sementara peserta didik merupakan orang-orang yang mencari ilmu, dalam artian luas peserta didik adalah anggota masyarakat yang belum dewasa dan memiliki potensi dalam dirinya secara fisik maupun psikis, memerlukan bantuan, arahan, bimbingan, dorongan dan hal sejenis dari orang lain, untuk mengembangkan dirinya melalui proses pendidikan pada berbagai jalur dan tingkatan tertentu (Saputra, 2015:242.

Berbicara tentang dunia Pendidikan, tak lepas dari sosok pembaharuan pemikiran Islam yakni para cendikiawan muslim seperti Syekh Ali Ashrafh, Zainudin Sardar, Syekh Muhammad Naquib Al-attas, Hamid Hasan Bilgrami, Ismail Raji Al faruqi, Nurchalish Madjid dan masih banyak Iagi cendikiawan Muslim lain yang peduIi dengan kondisi intelektual umat saat ini (Rusli, 2014). Muhammad Naquib al Attas bersama barisan cendikiawan Muslim lainnya mencemaskan realitas Pendidikan Islam yang berjalan selama ini, ia merupakan salah seorang pemikir Islam yang cukup tersohor, dikenal sebagai pemikir pendidikan islam yang cemerlang (Ghoni, 2017: 2). Beliau merupakan salah seorang pemikir cemerlang yang dimiliki Islam, yang memiliki perhatian besar terhadap dunia pendidikan.

Syekh Muhammad Naquib ibn Ali ibn Abdullah Ibn Muhsin Al-attas lahir pada 5 September 1931 di Bogor, Jawa Barat (Daud, 2003: 44). Ibunda Syekh Naquib, yaitu Syarifah Raquan Al 'Aydarus, berasal dari Bogor, Jawa Barat, dan merupakan keturunan ningrat Sunda di Sukapura, Syekh Naquib Al-attas adalah anak kedua dari tiga bersaudara. Yang sulung bernama Syekh Husein, seorang ahli sosiologi dan mantan Wakil Rektor Universitas Malaya, sedangkan yang bungsu bernama Syekh Zaid, seorang insinyur kimia dan mantan dosen 
Institut Teknologi MARA (Daud, 2003: 45-46). Latar belakang keluarga memberikan pengaruh yang besar dalam pendidikan awal Syekh Muhammad Naquib. Dari keluarganya yang terdapat di Bogor, dia memperoleh pendidikan dalam ilmu-ilmu keislaman, sedangkan dari keluarganya di Johor, dia memperoleh pendidikan yang sangat bermanfaat baginya dalam mengembangkan dasar-dasar bahasa, sastra, dan kebudayaan Melayu (Daud, 2003: 46).

Syekh Muhammad Naquib banyak menghabiskan masa mudanya dengan membaca dan mendalami manuskrip-manuskrip sejarah, sastra, dan agama, serta buku-buku klasik Barat dalam bahasa inggris yang tersedia di perpustakaan keluarganya yang lain. Lingkungan keluarga yang berpendidikan, fasilitas bahan bacaan yang memadai menjadi salah satu faktor pendukung Al-attas sehingga mampu mengembangkan gaya bahasa yang baik dan kosa kata yang tepat. Setelah menamatkan sekolah menengah pada 1951, Al-attas mendaftar di resimen Melayu sebagai kader nomor 6675. Al-attas terpilih sebagai Jendral Sir Gerald Templer, untuk mengikuti pendidikan militer, pertama di Eron Hall, Chester, Wales, kemudian di Royal Military Academy, Sandhurst, Inggris (1952-1955). Setamat dari Sandhurst, Al-attas ditugaskan sebagai pegawai kantor di resimen tentara kerajaan Malaya, namun ia tidak lama disini. Minatnya yang dalam untuk menggeluti ilmu pengetahuan mendorongnya untuk berhenti secara sukarela dari kepegawaiannya kemudian membawanya ke Universitas Malaya (1957-1959). Al-attas pindah ke SOAS, Universitas London untuk meneruskan pendidikan Doktoralnya. Pada tahun 1965 dia memperoleh gelar Ph.D. Al-attas kembali ke Malaysia pada 1965. Termasuk sedikit diantara orang malaysia pertama yang memperoleh gelas Doctor of Philosophy dan mendapatkannya dari Universitas London, Al-attas di lantik menjadi Ketua jurusan Sastra di Fakultas kajian Melayu Universitas Malaya, Kuala Lumpur. Dari 1968 sampai 1970, dia menjabat sebagai Dekan Fakultas Sastra di kampus yang sama (Daud, 2003: 47-50).

Pada penelitian terdahulu sudah ditemukan penelitian yang juga membahas mengenai pemikiran tokoh. Aristyasari dalam penelitian tersebut membahas mengenai konsep, tujuan dan sistem pendidikan Islam (Aristasyari,2013), namun dalam penelitian ini belum membahas mengenai pendidik dan juga peserta didik. Beliau menyimpulkan bahwa konsep dan pola pembaharuan pembaharuan terletak pada sistem dan tujuannya. Penelitian lainnya juga dilakukan oleh Ghoni yang juga membahas mengenai pemikiran pendidikan $\mathrm{Al}$ attas, dalam penelitian ini membahas pemikiran $\mathrm{Al}$ attas dalam pendidikan Islam Kontemporer (Ghoni, 2017). Yang menjadi fokus dalam penelitian ini adalah Pemikiran Pendidikan Islam Syekh Muhammad Naquib Al attas. Adapun yang menjadi ciri khas dan pembeda dalam penelitian ini adalah pendidikan islam al attas pada aspek tujuan, metode, kurikulum, pendidik dan peserta didik

\section{Metode}

Jenis penelitian ini yaitu penelitian kualitatif dalam kategori penelitian kepustakaan (library research). Yang memperoleh sumber data dari kepustakaan. Data kepustakaan yang digunakan adaah data kepustakaan yang berkaitan dengan pemikiran pendidikan Islam Syekh Muhammad Naquib Al-attas. Pengumpulan data dengan menggunakan studi dokumentasi dengan langkah mengumpulkan sekumpulan data dalam bentuk dokumen yang bekaitan dengan penelitian kemudian data di analisis dengan menggunakan teknik analisis konten.

\section{Hasil dan Pembahasan}

\section{A. Pemikiran Syekh Muhammad Naquib Al-attas tentang Pendidikan Islam}




\section{Tujuan Pendidikan}

Dalam islam ilmu itu merangkum iman dan kepercayaan. Tujuan dalam menuntut iImu adalah penanaman kebaikan atau keadilan dalam diri manusia sebagai manusia dan diri pribadi dan bukannya sebagai warga negara atau bagian yang tidak terpisahkan dari masyarakat. Inilah nilai manusia sebagai manusia sejati, sebagai penduduk dalam kota dirinya, sebagai warga negara dalam kerajaan mikrokosmiknya sendiri, sebagai ruh. Manusia bukan sekedar individu yang nilai ukurnya dalam pengertian pragmatis yang melihat kegunaannya bagi negara, masyarakat dan dunia (Al-attas, 2011).

Dalam merumuskan tujuan pendidikan Al-attas mengatakan bahwa tujuan dari pendidikan dalam Islam adalah untuk menanamkan kebaikan atau keadilan pada manusia sebagai manusia dan diri pribadi. Oleh karena itu untuk menciptakan manusia yang baik adalah tujuan pendidikan dalam islam. Penanaman adab adalah Unsur asasi yang terkandung dalam konsep pendidikan Islam, karena adab dalam artian luas di sini dimaksudkan meliputi kehidupan spiritual dan material manusia yang menumbuhkan sifat kebaikan yang dicarinya (Al-attas, 2011: 187).

Namun pendapat Al-attas ini tidak disepakati oIeh PIato karena menurut Plato tujuan dari pendidikan adalah pencapaian manusia yang berkerpibadian mulia dan memiliki taraf hidup kerohanian yang tinggi dan ideal sebagai warga negara yang terbina dan berkembang dengan sempurna (Nuthpaturahman, 2017). Al-attas punya argumentasi tersendiri menurutnya tujuan pendidikan bukanlah untuk mengembangkan ataupun membina warga negara yang baik, melainkan lebih penting dari pada itu yakni membina manusia yang sempurna, manusia yang baik, manusia yang beradab. Manusia beradab sebagai makhIuk sosial dan idealis yang meliputi kehidupan spiritual dan material, yang menitik beratkan pada pembentukan pribadi serta mengharapkan pembentukan masyarakat yang ideal. Karena masyarakat ideal terbentuk dari individu-individu yang baik.

Pendidikan Islam pada dasarnya berupaya untuk mewujudkan individu yang baik sesuai dengan fungsi utama penciptaannya oleh Allah SWT, ia membawa dua misi penting sekaligus sebagaimana yang telah termaktub dalam Alquran yakni sebagai hamba Allah SWT dan sebagai khalifah di bumi Allah. Oleh karena itu sistem pendidikan Islam seharusnya mampu merefleksikan ilmu dan akhlaq Rasulullah, dan kita sebagai umat islam berkewajiban untuk menampilkan kualitas keteladanan tersebut sesuai kemampuan yang kita miliki, seperti inilah poin yang dikehendaki oleh Al-attas (Daud, 2003: 212).

\section{Metode Pendidikan}

Dalam bidang metode Pendidikan Syekh Muhammad Naquib Al-attas muatan pendidikan itu sangat penting, ia merupakan prioritas tertinggi jika dibandingkan dengan metode. Ketika menekan pentingnya muatan pendidikan dari pada metode, Al-attas tidak sedikitpun bermaksud mengatakan bahwa metode tidak memiliki output positif terhadap pendidikan, tetapi menurut Al-attas adab itu sendiri sudah masuk ke dalam metode yang benar untuk mengetahui dan berbuat sesuatu (Daud, 2003: 267).

Pendidikan sebagai suatu proses penanaman adab ke dalam diri manusia yang merupakan sebuah proses yang sebenarnya tidak dapat diperoleh secara mutlak melalui metode khusus, ia menganggap bahwa dalam suatu proses pembelajaran, siswa akan mendemonstrasikan tingkat pemahamannya terhadap materi secara berbeda-beda, hal ini disebabkan karena ilmu dan hikmah yang merupakan dua komponen utama dalam konsepsi adab benar-benar merupakan suatu anugerah dari Allah swt (Daud, 2003: 266). Berikut uraian metode pendidikan beliau :

1. Metode Tauhid 
Ungkapan metode ini dapat digambarkan bahwa manusia menerima pengetahuan dan kearifan spiritual dari Allah melalui pengertian langsung atau penginderaaan. Salah satu karakteristik pendidikan dan espitemologi islam yang di jelaskan secara tajam dan dipraktekkan oleh Al-attas adalah apa yang dinamakan metode tauhid. Ungkapan metode ini dapat digambarkan bahwa manusia menerima pengetahuan dan kearifan spiritual dari Allah melalui pengertian langsung atau pengindraan. Allah adalah sang pemilik ilmu, Dia maha mengetahui, semua ilmu yang diserap dan dipahami oleh manusia itu semua sematamata karena Allah, Allah yang memberikan pemahaman akan ilmu tersebut kedalam hati dan fikiran manusia (Daud, 2003).

Al-attas menekankan dan menerangkan di beberapa tempat bahwa yang objektif dan yang subjektif tidak dapat dipisahkan, sebab hal itu merupakan aspek dari realitas yang sama sehingga satu sama lain saling melengkapi (Daud, 2003). Dia juga sering memberikan perumpamaan, seorang arsitek akan bisa bersikap objektif ketika dia melihat rumah yang telah di desain, seperti bentuk, tinggi, lebar, panjang dari tiap bagian. Namun ia tidak akan mengetahui keadaan yang sebenarnya dari rumah itu sebelum dia berdiam di rumah itu. Hanya dengan mendiami rumah tersebut baru dia akan tahu ruangan mana yang nyaman di rumah itu dan aspek subjektif ini tidak akan menghilangkan aspek luar yang objektif dari pengetahuan mengenai rumah tersebut (Daud, 2003).

Subjektif dan objektif merupakan dua hal yang saling berdampingan, dan hal yang subjektif tidak akan menghilangkan esensial dari keobjektifan segala sesuatu. Metode tauhid A1attas menjadi sangat pribadi, sehingga ia jengkel ketika ada beberapa orang yang merasa sudah memahami agama islam, prinsip-prinsipnya, konsepnya, etikanya bertanya mengenai cara mengimplementasikannya dalam kehidupan sehari-hari dan ke dalam profesi yang sedang mereka tekuni, Al-attas menggaris bawahi bahwa, jika seseorang telah benar-benar memahami itu semua, maka tidak akan muncul pertanyaan seperti itu, karena dalam islam tidak ada dikotomi antara teori dan praktek (Daud, 2003). ketika seseorang telah benar-benar memahami prinsip, konsep dan etika dalam islam secara benar, maka secara otomatis seseorang mestinya mampu melaksanakan praktiknya dalam kehidupan sehari-hari.

\section{Metode Metafora dan Cerita}

Ciri metode pendidikan Al-attas yang paling menonjol selanjutnya adalah penggunaan metafora dan cerita sebagai contoh dan perumpamaan (Daud, 2003: 290). Ciri metode pendidikan Al-attas yang paling menonjol selanjutnya adalah penggunaan metafora dan cerita sebagai contoh dan perumpamaan. Salah satu metafora yang pernah beliau sampaikan yakni lampu baru dan lampu lama tukang sulap yang melambangkan tiga kelompok utama pelestarian kehilangan adab pada zaman kita yang menimbulkan kebencian diantara generasi umat islam masa kini. Mereka hakikatnya bukanlah pemimpin sejati kita, tanpa mengenal dan tanpa arahan dari merekapun kita akan tetap bisa mengenal islam melalui para ulama kita dimasa lalu, sebaliknya tanpa mengetahui guru sejati dari masa lalu dan bimbingan mereka hampir tidak mungkin kita sampai pada pemahaman dan ilmu yang benar mengenai islam. Seakan-akan pemimpin palsu pada zaman kita sudah dibentuk dalam pola tukang sulap besar yang licik dalam penyamaran lampu-lampu baru untuk di tukarkan dengan lampu lama. Jangan sampai kita jatuh pada kesalahan yang sama dengan istri jahil aladin yang menukarkan yang tua dengan yang baru, tanpa 
menyadari nilai tak terkira dan mutu yang menakjubkan dari lampu lama yang jauh melampaui nilai semua lampu baru yang dijadikan satu (al-attas, 2011).

\section{Kurikulum Pendidikan}

Bangunan kurikulum Pendidikan islam menurut Al-attas berangkat dari pandangan bahwa manusia itu bersifat dualistik, jadi karena itu kandungan kurikulum harus memenuhi kedua aspek dasar tersebut. Pertama, memenuhi kebutuhan yang berdimensi permanen dan spiritual atau fardhu 'ain dan kedua, yang memenuhi kebutuhan material-emosional atau fardhu kifayah (Daud, 2003: 269).

Ilmu-ilmu yang masuk dalam kategori fardhu 'ain mencakup: membaca dan interpretasi Al qur'an, sunnah, syari'at, teologi, metafisika alam, ilmu bahasa. fardhu 'ain ini wajib dipelajari oleh masing- masing individu. Sementara Fardhu kifayah tidak diwajibkan kepada setiap muslim untuk mempelajarinya, tetapi seluruh masyarakat mukmin akan betanggung jawab jika tidak ada seorangpun yang mempelajarinya. Al-attas membagi pengetahuan Fardhu kifayah menjadi delapan disiplin ilmu diantaranya, ilmu kemanusiaan, ilmu alam, ilmu terapan, ilmu teknologi, perbangingan agama, kebudayaan barat, ilmu linguistik, sejarah islam (Daud, 2003: 274-277).

Fardhu 'ain dijadikan sebagai bangunan dasar bagi pengembangan selanjutnya, yang meliputi aspek keilmuan, life skill dan lain sebagainya. Jika aspek keilmuan sebagai salah satu dari sekian aspek yang ada dikembangkan berdasarkan bangunan dasar tadi maka hal ini akan menjadi media dalam memahami pencipta dalam bentuk ketundukan terhadap segala peraturan Allah SWT (Usman \& Surahim, 2005:139). Kurikulum yang ideal seharusnya berusaha untuk menciptakan insan kamil. Pemahaman akan bangunan dasar ini haruslah menjadi perhatian bagi setiap jenjang pendidikan yang ada dengan harapan agar peserta didik menjadi individu unggul secara spiritual dan intelektual (Sya'bani, 2019:22).

Ilmu fardhu 'ain maupun fardhu kifayah tidak bersifat statis hal ini dikarenakan keduanya akan terus berkembang sesuai dengan kemampuan yang dimiliki oleh seseorang baik dari segi spriritual maupun intelektual (Aristasyari, 2013: 10).

Al-attas tidak membatasi kedua ilmu tersebut yakni ilmu fardhu 'ain dan fardhu kifayah hal ini karena pengetahuan itu sebagi sifat tuhan, ia tidak terbatas, intekletual dan spiritual seseorang serta keadaan masyarakatnya. Ilmu fardhu 'ain tidak hanya diajarkan pada pendidikan tingkat dasar saja tetapi harus berlanjut sampai pendidikan menengah dan universitas. Karena universitas adalah tingkat pendidikan yang paling tinggi, maka perumusan ruang lingkupnya harus lebih di dahulukan pada tingkat ini sebelum diproyeksikan ketingkat bawah, sebab universitas menjadi model bagi pendidikan di bawahnya.

\section{Pendidik}

Syekh Muhammad Naquib Al-attas menekan bahwa pendidik bukan hanya pengajar yang tugasnya hanya mentransfer ilmu pengetahuan saja, melainkan juga seseorang yang melatih jiwa dan kepribadian peserta didik. Pedidik harus memiliki kepribadian dan adab yang baik sehingga mampu dijadikan teladan bagi peserta didiknya dan dapat membimbing dan membina dalam rangka menjadikannya manusia yang baik dan beradab sehingga menjadi individu yang baik, berakhlak mulia, jujur, berani dan bertanggung jawab.

Seorang pendidik dengan konsep ta'dib harus bisa mendisiplinkan jiwa dan pikiran untuk menunjukkan pendidikan intelektual, spiritual dan sosial bagi semua manusia sehingga dapat menceminkan karakteristik dan kepribadian yang luhur dalam setiap sendi kehidupannya 
sehingga ia mampu menjadi teladan dan panutan yang akan ditiru oleh pesera didik (Sukatno, 2014). Penghormatan terhadap pendidik akan menjadi kenyataan jika seorang pendidik tidak hanya sekedar punya otoritas dibidangnya saja, akan tetapi juga memberikan contoh secara konsisten. Karena seorang pendidik itu ditiru dan digugu oleh peserta didiknya. Maka pendidik harus terIebih dahulu menjadi sosok teladan yang patut dicontoh.

\section{Peserta Didik}

Adapun untuk peserta didik menurut Al-attas hendaklah tidak tergesa-gesa dalam menuntut ilmu, menyiapkan waktu untuk mencari seorang pendidik terbaik pada bidang keilmuan yang hendak dipelajari, hal ini senada dengan pendapat Al gazali (Nanu, 2021). Menurut Al-attas peserta didik bebas untuk menentukan dengan siapa dan dimana ia belajar untuk menggali ilmu pengetahuan, namun tetap memperhatikan kualitas seorang pendidik atau lembaga yang akan mengantarkan untuk mencapai tujuan agar tidak lepas dari hakikat utama pembelajaran yakni mencapai derajat individu yang beriImu dan beradab.

Peserta didik harus menyadari konsep keikhlasan, kejujuran dan juga kesabaran dalam menuntut ilmu karena itu merupakan etika, peserta didik harus mengenal dan dikenalkan prinsip ini sejak dini mempraktekkan dalam kehidupan sehari-hari (Daud, 2003). Peserta didik harus mengamalkan adab, yaitu mendisiplinkan pikiran dan jiwa. Peserta didik harus menghormati dan percaya kepada guru, harus sabar dengan kekurangannya dan menempatkannya dalam perspektif yang wajar (Al-attas, 2011). Dalam artian peserta didik wajib mengembangkan adab yang sempurna dalam ilmu pengetahuan, karena ilmu pengetahuan tidak bisa di ajarkan pada siapapun tanpa adab. Selain keikhlasan tujuan dan penghargaan terhadap ilmu guru menurut al-attas memahami dengan benar isi dan pesan yang disampaikan oleh guru mereka adalah penting.

\section{Simpulan}

Dalam perspektif Syekh Muhammad Naquib Al-attas Pendidikan merupakan proses penyerapan dan penanaman adab pada manusia yang bertujuan untuk melahirkan individu yang baik, individu yang beradab. Adapun metode yang beliau gunakan yakni ada dua, yang pertama metode tauhid dan yang kedua metode metafora. Sedangkan untuk kurikulum pendidikan beliau membaginya menjadi fardhu 'ain dan fardhu kifayah. Fardhu 'ain ialah ilmu yang memang wajib untuk dipelajari oleh masing-masing individu dan fardhu kifayah merupakan ilmu yang hanya di wajibkan untuk sebagian individu saja. Sementara itu pendidik bukan hanya pengajar yang tugasnya hanya mentransfer ilmu pengetahuan saja, ia harus memiliki kepribadian dan adab yang baik sehingga mampu dijadikan teladan bagi peserta didiknya dan peserta didik wajib mengembangkan adab yang sempurna dalam ilmu pengetahuan.

\section{Daftar Kepustakaan}

Al-Attas, S. M. N. (2011). Islam dan Sekularisme [Islam and Secularism], trans. Khalif Muammar A. Harris, Bandung: PIMPIN.

Asy’ari M. K. (2014) Metode Pendidikan Islam. Jurnal Qathruna 1(1) 
Barni, M. (2008) Dasar dan Tujuan Pendidikan Islam, jurnal Al banjari 7(1)

Daud, W. M. N. W., \& Nor, W. M. (2003). Filsafat dan Praktik Pendidikan Islam Syekh M. Naquib Al-Attas. Bandung: Mizan.

Ghoni, A. (2017). Pemikiran Pendidikan Naquib al-Attas dalam Pendidikan Islam Kontemporer. Jurnal Lentera: Kajian Keagamaan, Keilmuan dan Teknologi, 3(1), 196-215.

Hirnawan, L. A. (2020). Konsep Ta'dib An-Naquib Al-Attas dan Humanisme Paulo Freire serta Relevansinya dengan Pendidikan Islam.

Malli, R. (2014). Pemikiran Pendidikan Islam. PILAR, 5(2).

Muhaemin dan Bulu'k (2014) ilmu pendidikan Islam Palopo: Read Institute press.

Nanu, R. P. (2021). Pemikiran Syekh Muhammad. Naquib Al-Attas terhadap Pendidikan di Era Modern. TARBAWI: Jurnal Pendidikan Agama Islam, 6(01), 14-29.

Nuthpaturahman, N. (2018). Epistemologi Idealisme Plato; Implikasi terhadap Lahirnya Teori Fitrah dalam Pendidikan Islam. Ittihad, 15(28), 1-16.

Saputra M. I. (2015) Hakikat Pendidik dan Peserta Didik dalam Pendidikan Islam. At tadzkiyyah: Jurnal Pendidikan Islam, 6(1)

Satria, R. (2019). Pembaruan Pendidikan Islam di Madrasah Tarbiyah Islamiyah Canduang. Geneologi PAI: Jurnal Pendidikan Agama Islam, 6(1), 15-22.

Syafe'I I. (2015). Tujuan Pendidikan Islam. At tadzkiyyah : Jurnal Pendidikan Islam, 6(1) 